\title{
The impact of the COVID-19 pandemic on quality of life and well-being in Morocco
} Samlani $Z^{1}$, Lemfadli $Y^{1^{*}}$, Ait Errami $A^{1}$, Oubaha $S^{2}$, Krati $K^{1}$

${ }^{1}$ Gastroenterology Department, Mohammed VI University Hospital, Marrakech

${ }^{2}$ Physiology Department, Faculty of Medicine and Pharmacy at Cadi Ayyad University, Marrakech

\begin{abstract}
Introduction:

The majority of epidemiological reports focus on confirmed cases of COVID-19. In this study, we aim to assess the health and well-being of adults not infected with Covid-19 after two months of quarantine in Morocco.
\end{abstract}

\section{Materials and methods:}

Two months after the declaration of quarantine in Morocco following the Covid-19 epidemic, we carried out a descriptive cross-sectional study of 279 Moroccan citizens. We used the Short Form Health Survey (SF-12) as a determinant of quality of life, which is based on eight dimensions of health. The data were collected using an electronic questionnaire distributed online. The participants also indicated their socio-demographic data, their knowledge and practices regarding the Covid-19 pandemic and whether they had chronic health problems.

\section{Results:}

The quality of life of all participants was moderately disrupted during the Covid-19 pandemic with a mental health score (MCS) of 34.49 ( \pm 6.44) and a physical health score (PCS) of 36.10 ( \pm 5.82$)$. Participants with chronic diseases scored lower with $29.28( \pm 1.23)$ in mental health (MCS) and 32.51 ( \pm 7.14$)$ in physical health (PCS). The seriousness of COVID-19 has an impact on the quality of life and health well-being of people and this impact is more marked in people with chronic health problems.

\section{Conclusion:}

Our results confirm the need to pay attention to the health of people who have not been infected with the virus. Our results also point out that uninfected people with chronic illnesses may be more likely to have well-being problems due to quarantine restrictions.

Keywords: Covid-19, quality of life, mental health, physical health 


\section{Introduction}

The appearance of a new coronavirus disease (COVID-19) was first reported in December 2019 in Wuhan, China [1]. The number of cases has increased exponentially not only in China but in the world. The Moroccan health authorities announced the first confirmed case of Covid-19 on March 2, 2020. COVID-19 was officially declared a pandemic by the world health organization on March 11, 2020 [2]. From December 2019 until the time of writing this article, 11, 4 million cases of COVID-19 have been confirmed worldwide and more than 535000 people have died [3]. This pandemic has put global public health institutions on alert $[4,5,6]$. Morocco, like many countries in the world, declared a state of health emergency and quarantine on March 20, 2020.

Admittedly, quarantine and the state of health emergency have a great interest in controlling the spread of the pandemic [7]. However, it is also important to understand the implications of these restrictions on the health and well-being of the community.

We hypothesized that health-related quality of life is more likely to be affected during the COVID-19 pandemic.

Therefore, we aim in this study to provide an analysis of the health and well-being of a sample of the general population during the quarantine period.

\section{Materials and methods :}

\section{Characteristics of the participants:}

We conducted a descriptive cross-sectional online survey about two months after the declaration of quarantine and the COVID-19 state of emergency in Morocco. All participants were adults over the age of 18 , resident in Morocco who were not epidemiologically infected with the virus, but they lived in places affected by COVID-19. To have a representative national sample and cover people in areas of varying severity of COVID-19, we interviewed citizens across the 12 regions of Morocco.

\section{Study procedure:}

Given the circumstances of the quarantine, the study announcements, containing brief information about the study and a link to a web page, were shared by e-mail (to personal and professional networks), and published on Facebook and other popular social media websites, including Twitter and Instagram. The online survey was administered by Google Forms to 
ensure wide reach and easy access. Participants were asked to share the survey with their families and acquaintances.

Responses to all elements of the questionnaire were required, and respondents could only submit their responses if all questions were answered. The data reported in this study was collected between May 25 and June 6, 2020.

Participation was voluntary and all participants gave informed consent electronically and without any remuneration for their participation. No identifying information was collected to protect the anonymity of participants.

\section{Variables studied:}

Participants provided their socio-demographic characteristics, such as gender, age, education and residence (region and city) as well as their knowledge and practices regarding the Covid19 pandemic. Given that COVID- 19 is more dangerous for people with co-morbidities [8], so we asked if the participants had a chronic disease.

We assessed individual health using the Short Form-12 (SF12). We used a Moroccan version validated in Arabic and French [9]. SF12 contains 12 elements and 8 dimensions: physical activity ( 2 elements), limitations due to physical activity ( 2 elements), physical pain (1 element), perceived general health (1 element), vitality (1 element), social functioning (1 element), limitations due to mental state (2 elements) and mental health (2 elements) [10]. The eight dimensions form two physical and mental subscores (PCS and MCS), with a possible total score ranging from 0 to 100 [11]. A higher SF12 score indicates better health.

\section{Statistical analyzes:}

We report descriptive statistics of the study variables. The analyzes were performed by IBM SPSS Statistics v 21. We used the t-student test to compare the means of the summary physical and mental scores of the SF-12, after having checked the normality of the distribution of the two scores. The materiality threshold was set at 0.05 .

\section{Results:}

279 participants responded to the survey. Table (1) presents the descriptive characteristics of the participants. The average age was 34.75 years $( \pm 11.8)$. The majority of participants were men $(51.6 \%)$, singles $(66.3 \%)$ and those with a university level (88.9\%). All regions were 
represented. The Marrakech -Safi region was the most represented (25.40\%). $13.3 \%$ of the participants indicated that they have a family member or know a loved one with a confirmed Covid-19 infection. $10.40 \%$ of the participants reported that they suffered from chronic diseases.

Regarding participants' knowledge of Covid-19 (table 2): $76.4 \%$ think it is a dangerous disease and $30 \%$ think it is fatal in 15 to $40 \%$ of cases. $90 \%$ believe that transmission is through the droplets of an infected person. The most vulnerable group according to participants is the elderly and people with chronic diseases in $87.1 \%$ and $91.8 \%$ of the responses respectively. The majority of respondents reported fever, cough and difficulty breathing as major symptoms of the disease in $95.7 \%, 93.2 \%$ and $88.5 \%$ of the responses. $62.70 \%$ of participants believe that there is no specific current treatment for Covid-19 infection. $95.69 \%$ of participants believe that wearing a mask is effective in preventing Covid19 infection.

Concerning the practices of the population in the face of the Covid-19 pandemic (table 3): The majority of participants $(96.77 \%)$ report that they follow the health recommendations for coronavirus and $75.95 \%$ comply with the quarantine recommendations in more than $80 \%$ (Figure 1). 90.32\% of the respondents report that they always wear the mask when leaving the house. $97.50 \%$ of participants wash their hands daily at least with soap and water.

Participants' fear of catching the coronavirus was assessed using an increasing numerical scale from 1 to 10 (Figure 2). $60.6 \%$ of the participants reported a fear less than or equal to 5 degrees. 
Figure 1: Level of commitment of participants in quarantine

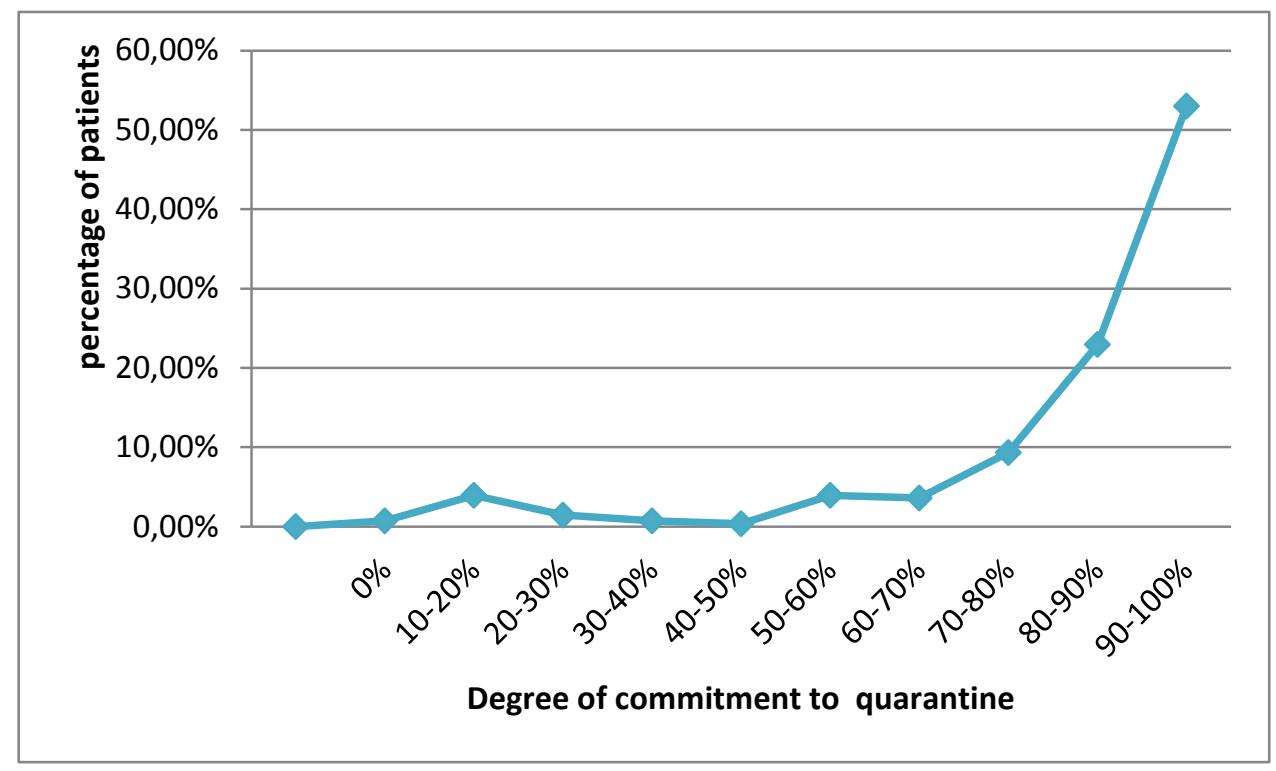

Figure 2: Level of fear of Covid-19 participants

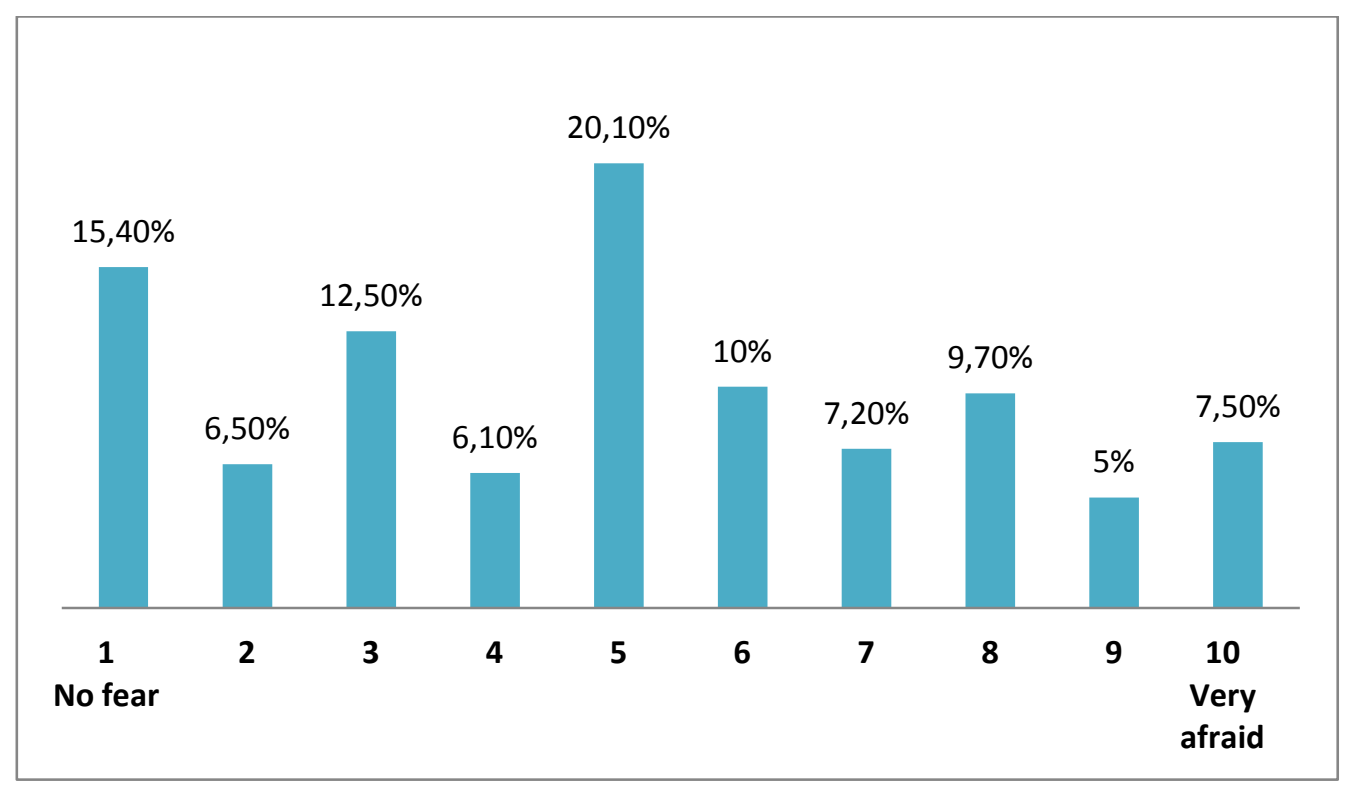

Based on the SF12 algorithm [9], all participants obtained a total average score of 70.60 ( \pm $13.1)$ with a mental health score (MCS) of $34.49( \pm 6.44)$ and a physical health score (PCS) of 36.10 ( \pm 5.82 ). The physical (PCS) and mental (MCS) scores of participants with chronic diseases were $32.51( \pm 7.14)$ and $29.28( \pm 1.23)$, respectively (Table 4).

Overall, the participants' PCS and MCS scores suffered from chronic diseases and the elderly participants were lower than those of young participants without comorbidities (Figure 3). 
Figure 3: Quality of life score for participants according to age and the presence of comorbidities

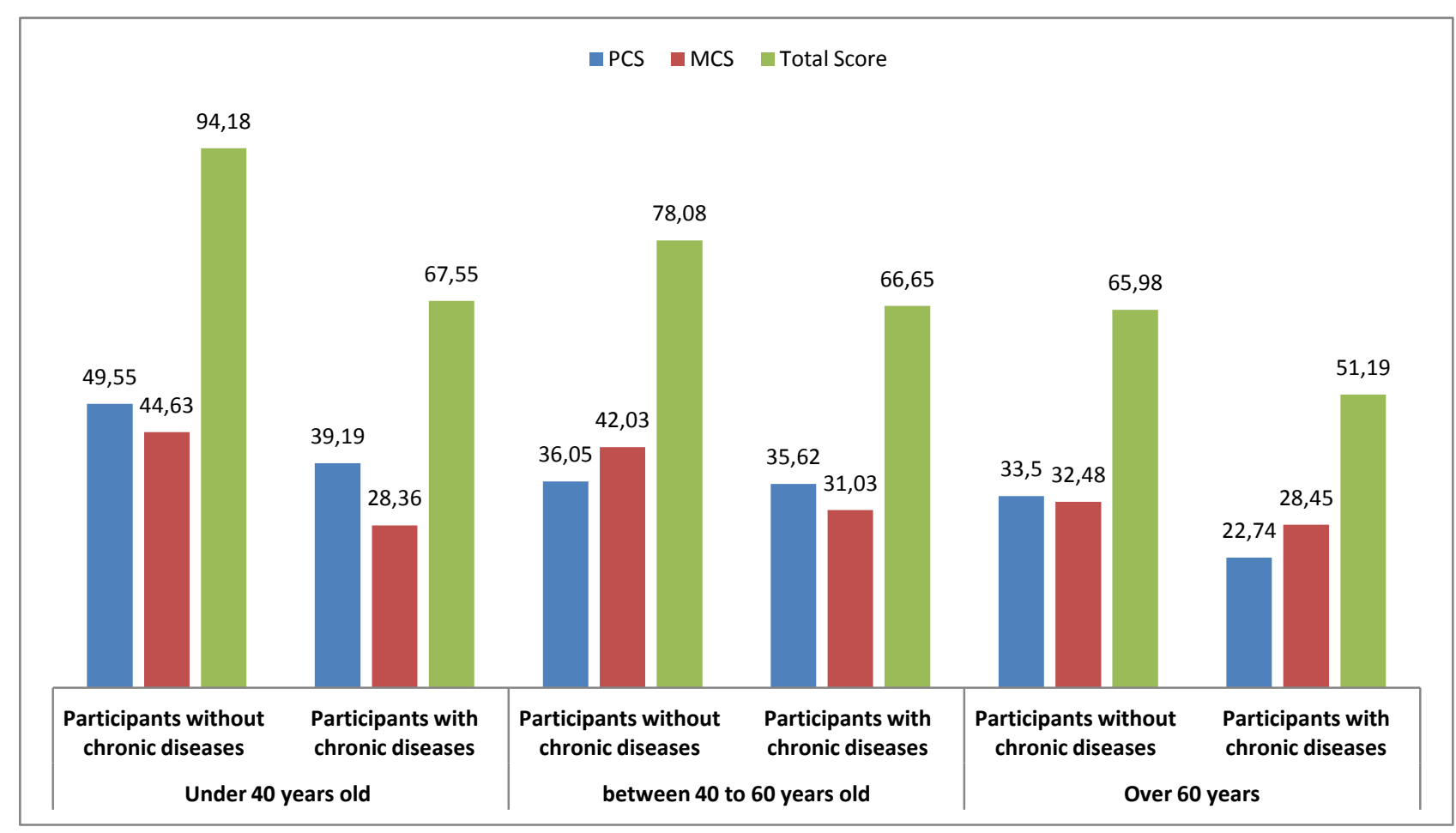

MCS: Mental Component Summary PCS: Physical Component Summary

\section{Discussion:}

Restrictive measures applied in several countries around the world appear to be effective in containing the spread of COVID-19 [7]. However, these measures have disrupted people's daily employment and daily activities and can therefore have important implications for their health and well-being. [12]

As was the case previously with the Middle East respiratory syndrome coronavirus (MERS$\mathrm{CoV})[13,14]$, the COVID-19 pandemic also causes panic and mental health problems for the general population $[15,16.17]$. In addition, quarantine could affect the psychological health of the public $[18,19]$. This can influence the general health and quality of life of people.

People with chronic health conditions are vulnerable populations with a lower quality of life during this Covid-19 crisis [20]. However, health systems have largely neglected this fragile population [21].

Our results show that the quality of life linked to the general health of people in quarantine is poor and especially if there are chronic health problems, as shown by SF12. Insignificant differences in some dimensions of SF12 (body pain, physical functioning and social functioning) were present, since people who had not been directly affected by the virus would not differ much in these dimensions. 
An article published on Lancet pointed out that people in quarantine have reported a high prevalence of symptoms of distress and psychological disorders and some of these symptoms seem to persist long after quarantine [22].

We may need to pay more attention to those affected and those with co-morbidities, but also physically active people, who may be more frustrated with the quarantine restrictions. Such identification can help health systems prioritize those who may have more impact during this health crisis.

We present this data on general quality of life disruptions to provide evidence on the health of the community during this Covid-19 crisis.

The study has certain limitations. First of all, this study was based on a cross-sectional observation survey. The data do not allow conclusions to be drawn about the nature or the orientation of the associations examined. We also do not know whether this lower quality of life existed before COVID-19.

Likewise, online self-assessment questionnaires may be influenced by the difficulty of completing them. This could affect the validity of the data provided.

Given our recruitment methods and our sample size, the results may not be generalized to the entire population of Morocco and other countries. Nevertheless, the hypotheses reported could be targets for future studies.

\section{Conclusion}

The results underscore the importance of social ties to mitigate the negative consequences of the COVID-19 pandemic on mental health and physical well-being. Policymakers managing the COVID-19 pandemic can benefit from understanding these implications for the health and well-being of the population, especially the elderly and those with chronic diseases.

\section{Conflict of Interest Statement}

We declare no competing interests.

\section{Acknowledgments}

None 


\section{References :}

[1].Ren, L.-L.; Wang, Y.-M.; Wu, Z.-Q.; Xiang, Z.-C.; Guo, L.; Xu, T.; Jiang, Y.-Z.; Xiong, Y.; Li, Y.-J.; Li, X.-W.; et al. Identification of a novel coronavirus causing severe pneumonia in human: A descriptive study. Chin. Med. J. (Engl.) 2020. [CrossRef] [PubMed]

[2]. World Health Organisation. WHO Director-General's Opening Remarks at the Media Briefing on COVID-19-11 March 2020; WHO: Geneva, Switzerland; Available online: https://www.who.int/dg/speeches/detail/ who-director-general-s-openingremarks-at-the-media-briefing-on-covid-19---11-march-2020.

[3]. World Health Organisation. WHO Director-General's Opening Remarks at the Media Briefing on COVID-19-11 7 July 2020. Available online: https://www.who.int/fr/dg/speeches/detail/who-director-general-s-opening-remarks-atthe-media-briefing-on-covid-19---7-july-2020

[4].Wang, C.; Horby, P.W.; Hayden, F.G.; Gao, G.F. A novel coronavirus outbreak of global health concern. Lancet 2020, 395, 470-473. [CrossRef]

[5].Thompson, R. Pandemic potential of 2019-nCoV. Lancet Infect. Dis. 2020. [CrossRef]

[6].Wu, J.T.; Leung, K.; Leung, G.M. Nowcasting and forecasting the potential domestic and international spread of the 2019-nCoV outbreak originating in Wuhan, China: A modelling study. Lancet 2020. [CrossRef]

[7].J. Bedford, D. Enria, J. Giesecke, et al.COVID-19: towards controlling of a pandemic , Lancet, 395 (2020), pp. 1015-1018

[8].Gates B. Responding to Covid-19-A once-in-a-century pandemic? New England Journal of Medicine. New Engl J Med 2020. published online Feb 28. https://doi.org/10.1056/NEJMp2003762 
[9].M. Hicham Sehli «Adapatation transculturelle du questionnaire SF-12 » Thèse doctorat médecine, Fès,. Page ;39. 2007

[10]. Ware J, Jr, Kosinski M, Keller SD. A 12-Item Short-Form Health Survey: construction of scales and preliminary tests of reliability and validity. Med Care 1996; 34(3): $220-233$

[11]. Ware JE, Kosinski M, Turner-Bowker DM, Gandek B, QualityMetric Incorporated. How to score version 2 of the SF-12 Health Survey (with a supplement documenting version 1) Lincoln: QualityMetric Inc.; 2002.

[12]. Galea, S., Merchant, R. M., \& Lurie, N. (2020). The mental health consequences of COVID-19 and physical distancing: the need for prevention and early intervention. JAMA Internal Medicine. https://doi.org/10.1001 /jamainternmed.2020.1562

[13]. Jack, A. Why the panic? South Korea's MERS response questioned. BMJ (Clin. Res. Ed.) 2015, 350, h3403.

[14]. Abdel-Moneim, A.S. Middle-East respiratory syndrome coronavirus: Is it worth a world panic? World J. Virol.2015, 4, 185-187.

[15]. S.X. Zhang, Y. Wang, A. Rauch, F. Wei. Health, distress and life satisfaction of people in China one month into the COVID-19 outbreak. Psychiatry Res., 288 (2020), Article 112958 . doi:2020.03.13.20034496

[16]. Bao, Y.; Sun, Y.; Meng, S.; Shi, J.; Lu, L. 2019-nCoV epidemic: Address mental health care to empower society.Lancet 2020.

[17]. Xu, Z.; Li, S.; Tian, S.; Li, H.; Kong, L.-Q. Full spectrum of COVID-19 severity still being depicted. Lancet 2020 .

[18]. Shimizu, K. 2019-nCoV, fake news, and racism. Lancet 2020. 
[19]. Brooks, S.K.;Webster, R.K.; Smith, L.E.;Woodland, L.;Wessely, S.; Greenberg, N.; Rubin, G.J. The psychological impact of quarantine and how to reduce it: Rapid review of the evidence. Lancet 2020.

[20]. Nguyen, H. C. , Nguyen, M. H. , Do, B. N. , Tran, C. Q. , Nguyen, T. T. P. , Pham, K. M. , ... Duong, T. V. (2020). People with suspected COVID-19 symptoms were more likely depressed and had lower health-related quality of life: The potential benefit of health literacy. Journal of Clinical Medicine, 9, 965.

[21]. Lloyd-Sherlock Peter, Ebrahim Shah, Geffen Leon, McKee Martin. Bearing the brunt of covid-19: older people in low and middle income countries BMJ 2020;368:m1052 doi: https://doi.org/10.1136/bmj.m1052

[22]. Wang C, Horby P W, Hayden F G, Gao G F. A novel coronavirus outbreak of global health concern. Lancet 2020; 395(10223): 470-473. 
$\underline{\text { Table 1: description of participants }(n=279)}$

\begin{tabular}{|c|c|c|c|}
\hline & & Number of participants & Percentage \\
\hline Age (years) & $\begin{array}{l}\text { Age (years) Mean } \pm \text { SD } \\
\text { Extremes ( years) }\end{array}$ & $\begin{array}{l}29.03 \pm 9.85 \\
18-68\end{array}$ & - \\
\hline Gender & $\begin{array}{l}\text { Male } \\
\text { Female }\end{array}$ & $\begin{array}{l}144 \\
135\end{array}$ & $\begin{array}{l}51.60 \% \\
48.40 \%\end{array}$ \\
\hline Marital status & $\begin{array}{l}\text { Single } \\
\text { Married } \\
\text { Divorced } \\
\text { Widower }\end{array}$ & $\begin{array}{l}185 \\
90 \\
4 \\
0\end{array}$ & $\begin{array}{l}66.30 \% \\
32,30 \% \\
1,40 \% \\
0 \%\end{array}$ \\
\hline Education level & $\begin{array}{l}\text { Unschooled } \\
\text { Primary } \\
\text { Secondary } \\
\text { University }\end{array}$ & $\begin{array}{l}0 \\
2 \\
29 \\
248\end{array}$ & $\begin{array}{l}0 \% \\
0.71 \% \\
10.39 \% \\
88.90 \%\end{array}$ \\
\hline Residence & $\begin{array}{l}\text { Urban } \\
\text { Rural }\end{array}$ & $\begin{array}{l}246 \\
33\end{array}$ & $\begin{array}{l}88.2 \% \\
11.8 \%\end{array}$ \\
\hline Region & $\begin{array}{l}\text { Tangier-Tetouan-Al Hoceïma region } \\
\text { Oriental region } \\
\text { Fez-Meknes region } \\
\text { Region of Rabat-Salé-Kénitra } \\
\text { Béni Mellal-Khénifra region } \\
\text { Casablanca-Settat region } \\
\text { Marrakech-Safi region } \\
\text { Drâa-Tafilalet region } \\
\text { Souss-Massa region } \\
\text { Guelmim-Oued Noun region } \\
\text { Laâyoune-Sakia El Hamra region } \\
\text { Dakhla-Oued Ed Dahab region }\end{array}$ & $\begin{array}{lr}13 & \\
4 & \\
14 & \\
26 & \\
68 & \\
34 & \\
71 & \\
& 8 \\
& 27 \\
6 & \\
5 & \\
3 & \end{array}$ & $\begin{array}{l}4.70 \% \\
1.40 \% \\
5,00 \% \\
9.30 \% \\
24.40 \% \\
12.20 \% \\
25.40 \% \\
2.80 \% \\
9.70 \% \\
2.20 \% \\
1.80 \% \\
1.10 \%\end{array}$ \\
\hline Chronic disease & $\begin{array}{l}\text { Yes } \\
\text { No }\end{array}$ & $\begin{array}{l}29 \\
250\end{array}$ & $\begin{array}{l}10.40 \% \\
89.60 \%\end{array}$ \\
\hline $\begin{array}{l}\text { Covid-19 infection } \\
\text { confirmed in family } \\
\text { member or relative }\end{array}$ & $\begin{array}{l}\text { Yes } \\
\text { No }\end{array}$ & $\begin{array}{l}37 \\
242\end{array}$ & $\begin{array}{l}13.30 \% \\
86.70 \%\end{array}$ \\
\hline
\end{tabular}


Table 2: participants' knowledge of the Covid-19 $(\mathrm{n}=279)$

\begin{tabular}{|c|c|c|c|}
\hline & & Number of participants & Percentage \\
\hline $\begin{array}{l}\text { Do you think Covid-19 } \\
\text { is a serious disease? }\end{array}$ & $\begin{array}{l}\text { Yes } \\
\text { No } \\
\text { I do not know }\end{array}$ & $\begin{array}{l}213 \\
33 \\
33\end{array}$ & $\begin{array}{l}76.40 \% \\
11.80 \% \\
11.80 \%\end{array}$ \\
\hline $\begin{array}{l}\text { How are people infected } \\
\text { with COVID-19? }\end{array}$ & $\begin{array}{l}\text { By droplets } \\
\text { By contact with infected surfaces } \\
\text { Eating bats } \\
\text { By blood } \\
\text { By air }\end{array}$ & $\begin{array}{l}249 \\
264 \\
84 \\
78 \\
134\end{array}$ & $\begin{array}{l}89.24 \% \\
94.62 \% \\
30.10 \% \\
27.95 \% \\
48.02 \%\end{array}$ \\
\hline $\begin{array}{l}\text { People most vulnerable } \\
\text { to covid-19 infection }\end{array}$ & $\begin{array}{l}\text { Infants } \\
\text { Children } \\
\text { Young adults } \\
\text { Pregnant woman } \\
\text { The elderly } \\
\text { People with chronic diseases }\end{array}$ & $\begin{array}{l}72 \\
55 \\
72 \\
105 \\
243 \\
256\end{array}$ & $\begin{array}{l}25.80 \% \\
19.70 \% \\
25.80 \% \\
37.60 \% \\
87.10 \% \\
91.80 \%\end{array}$ \\
\hline Symptoms of Covid-19 & $\begin{array}{l}\text { Fever } \\
\text { Dry cough } \\
\text { Headache } \\
\text { Stuffy nose } \\
\text { Runny nose } \\
\text { Sneeze } \\
\text { Difficulty breathing } \\
\text { Abdominal pain } \\
\text { Diarrhea } \\
\text { Asymptomatic }\end{array}$ & $\begin{array}{l}267 \\
247 \\
208 \\
82 \\
97 \\
144 \\
260 \\
89 \\
158 \\
219\end{array}$ & $\begin{array}{l}95.70 \% \\
88.50 \% \\
74.60 \% \\
29.40 \% \\
34.80 \% \\
51.60 \% \\
93.20 \% \\
31.90 \% \\
56.60 \% \\
78.50 \%\end{array}$ \\
\hline Treatment of Covid-19 & $\begin{array}{l}\text { There is an effective treatment for the virus } \\
\text { There is only symptomatic treatmen } \\
\text { There are drugs in the testing phase } \\
\text { A vaccine has been developed } \\
\text { Antibiotics are effective }\end{array}$ & $\begin{array}{l}30 \\
175 \\
224 \\
20 \\
65\end{array}$ & $\begin{array}{l}10.75 \% \\
62.72 \% \\
80.20 \% \\
7.16 \% \\
23.30 \%\end{array}$ \\
\hline $\begin{array}{l}\text { Prevention of Covid-19 } \\
\text { infection is based on? }\end{array}$ & $\begin{array}{l}\text { wearing a mask } \\
\text { avoid crowded places } \\
\text { Isolation of infected people } \\
\text { Isolation of suspected people } \\
\text { Healthy eating } \\
\text { Use of herbal remedies }\end{array}$ & $\begin{array}{l}267 \\
274 \\
274 \\
272 \\
153 \\
43\end{array}$ & $\begin{array}{l}95.69 \% \\
98.20 \% \\
98.20 \% \\
97.49 \% \\
54.84 \% \\
15.41 \%\end{array}$ \\
\hline $\begin{array}{l}\text { The Covid-19 is deadly } \\
\text { in? }\end{array}$ & $\begin{array}{l}\text { Less than } 10 \% \text { of cases } \\
10 \text { to } 40 \% \\
40 \% 60 \% \\
60 \text { to } 85 \% \\
\text { Over } 85 \% \text { of cases }\end{array}$ & $\begin{array}{l}150 \\
63 \\
31 \\
22 \\
13\end{array}$ & $\begin{array}{l}53.76 \% \\
22.58 \% \\
11.11 \% \\
7.89 \% \\
4.66 \%\end{array}$ \\
\hline
\end{tabular}


Table 3: Practices of participants regarding the Covid-19 pandemic $(\mathrm{n}=279)$

\begin{tabular}{|c|c|c|c|}
\hline & & Number of participants & Percentage \\
\hline $\begin{array}{l}\text { Search for medical } \\
\text { information on Covid- } \\
19 \text { to stay up to date } \\
\text { with the latest news }\end{array}$ & $\begin{array}{l}\text { Yes } \\
\text { No }\end{array}$ & $\begin{array}{l}233 \\
46\end{array}$ & $\begin{array}{l}83.51 \% \\
16.49 \%\end{array}$ \\
\hline $\begin{array}{l}\text { Compliance with } \\
\text { official } \\
\text { recommendations } \\
\text { against the pandemic }\end{array}$ & $\begin{array}{l}\text { Yes } \\
\text { No }\end{array}$ & $\begin{array}{l}270 \\
9\end{array}$ & $\begin{array}{r}96.77 \% \\
\quad 3.23 \\
\%\end{array}$ \\
\hline $\begin{array}{l}\text { Daily hand washing at } \\
\text { least with soap }\end{array}$ & $\begin{array}{l}\text { Yes } \\
\text { No } \\
\text { Sometimes }\end{array}$ & $\begin{array}{l}272 \\
3 \\
4\end{array}$ & $\begin{array}{l}97.50 \% \\
1.07 \% \\
1.43 \%\end{array}$ \\
\hline Wearing a mask outside & $\begin{array}{l}\text { Yes } \\
\text { No } \\
\text { Sometimes }\end{array}$ & $\begin{array}{l}252 \\
11 \\
16\end{array}$ & $\begin{array}{l}90.32 \% \\
\quad 3.95 \\
\% \\
5.73 \%\end{array}$ \\
\hline $\begin{array}{lr}\text { Percentage } & \text { of } \\
\text { compliance } & \text { with } \\
\text { quarantine } & \end{array}$ & $\begin{array}{l}0 \% \\
10-20 \% \\
20-30 \% \\
30-40 \% \\
40-50 \% \\
50-60 \% \\
60-70 \% \\
70-80 \% \\
80-90 \% \\
90-100 \%\end{array}$ & $\begin{array}{l}2 \\
11 \\
4 \\
2 \\
1 \\
11 \\
10 \\
26 \\
64 \\
148\end{array}$ & $\begin{array}{l}0.72 \% \\
3.94 \% \\
1.44 \% \\
0.72 \% \\
0.36 \% \\
3.94 \% \\
3.60 \% \\
9.33 \% \\
22.95 \% \\
53 \%\end{array}$ \\
\hline
\end{tabular}

Table 4: Quality of life results by SF12 $(\mathrm{n}=279)$

\begin{tabular}{|l|l|l|l|}
\hline Age & & Participants without chronic diseases & Participants with chronic diseases \\
\hline \multirow{2}{*}{$\begin{array}{l}\text { Less than 40 years } \\
\text { old }\end{array}$} & PCS (average) & 49,55 & 39,19 \\
\cline { 2 - 4 } & MCS (average) & 44,63 & 28,36 \\
\cline { 2 - 4 } Between 40 and 60 & Total Score (average) & 94.18 & 67.55 \\
\cline { 2 - 4 } years old & PCS (average) & 36,05 & 35,62 \\
\cline { 2 - 4 } & MCS (average) & 42,03 & 31,03 \\
\cline { 2 - 4 } & Total Score (average) & 78.08 & 66.65 \\
\hline \multirow{3}{*}{ Over 60 years } & PCS (average) & 33,5 & 22,74 \\
\cline { 2 - 4 } & MCS (average) & 32,48 & 28,45 \\
\cline { 2 - 4 } & Total Score (average) & 65.98 & 51.19 \\
\hline
\end{tabular}

MCS: Mental Component Summary PCS: Physical Component Summary 